\title{
A NEW VIEWPOINT ON GENETIC DIVERSITY IN PRESTICE BLACK-PIED PIG: DID THE BREED SUFFER FROM A BOTTLENECK?
}

\author{
Lenka Falková1, Irena Vrtková1, Štěpán Vrtek² \\ ${ }^{1}$ Laboratory of Agrogenomics, Department of Animal Morphology, Physiology and Genetics, Faculty \\ of AgriSciences, Mendel University in Brno, Zemědělská 1, 61300 Brno, Czech Republic \\ ${ }^{2}$ an external expert without affiliation to any institution
}

Link to this article: https://doi.org/10.11118/actaun202068020305

Received: 6. 2. 2020, Accepted: 31. 3. 2020

To cite this article: FALKOVÁ LENKA, VRTKOVÁ IRENA, VRTEK ŠTĚPÁN. 2020. A New Viewpoint on Genetic Diversity in Prestice Black-Pied Pig: Did the Breed Suffer from a Bottleneck? Acta Universitatis Agriculturae et Silviculturae Mendelianae Brunensis, 68(2): 305-309.

\begin{abstract}
The research was aimed at determination of genetic variability of Prestice Black-Pied (PC) pig breed (Czech national breed and genetic resource) and to evaluate possible presence of recent bottleneck in this closed small pig population. One hundred and eighty of breeding boars were analysed by eleven tetramer Short Tandem Repeats (STR) panel specifically developed for the genotyping of breeding livestock. Despite the fact that appearance of rare alleles, which may be relatively increased after recent bottleneck, was discovered, the heterozygosity excess was not significant. The PC breed has not undergone recent bottleneck and remained at mutation-drift equilibrium.
\end{abstract}

Keywords: bottleneck effect, genetic variability, genetic resource, Prestice Black-Pied pig

\section{INTRODUCTION}

The Prestice Black-Pied pig breed is registered as threatened with extinction by the UN FAO and was declared as a unique breed in 1964. Since 1992 the breed has been classified as Animal Genetic Resource (Václavková et al., 2012) and since 1996 has been bred in a closed population.

The genetic resources provide a wide and important pool of study. The using of genetic markers gives knowledge of molecular structure of the population and helps to protect them. These populations are not affected by selection as commercial hybrids. In general, low genetic diversity poses extinction danger and requires conservation measures. The research of genetic diversity helps to manage a preservation and conservation process. The irreversible genetic diversity loss is caused by extinction of endangered farm animal breeds. The usage of various genetic markers leads to evaluation of the observed phenotypic variability. A crucial importance for ability of population to acclimatize to environmental changes and a pressure of selection is played by its genetic variability - diversity. One of the first steps in the creation of conservation programs for endangered population is to evaluate the real situation of its genetic variability (Toro et al., 2011). Acknowledgement of genetic population structure, among populations and inside population, is essential in order to assign priorities and approaches of conservation and sustainability of small populations. Also, keeping of low inbreeding level is important for avoiding undesirable effects on health and economic traits. The livestock genetic diversity decrease is probably caused by the natural habitats of livestock breeds damage, the genetic uniformity by artificial breeding and human preferences for particular varieties and breeds and their changes overtime (Gholizadeh et al., 2008).

The molecular markers enable to characterize genetic variation. For a genetic variability evaluation, mainly Short Tandem Repeats (STR; 
microsatellites) are used nowadays. However, there are known many Single Nucleotide Polymorphism (SNP) markers, which could in the future substitute STR markers in an evaluation of diversity. To study population structure and variability of some species, these markers have been successfully used (e.g. Vrtková et al., 2012; Falková and Vrtková, 2017).

The bottleneck effect occurs in endangered species and leads to genetic diversity and evolutional potential loss. Considerable decline of allelic diversity, heterozygosity and loci polymorphism is caused by bottlenecks, as well as the allele frequencies distributions changes. Maruyama and Fuerst (1985) stated that most alleles, especially the alleles with a low frequency, can be lost after bottleneck. The occurrence of rare alleles may increase relatively in the population that has undergone bottleneck. The genetic variation loss is expected whenever the population went through bottleneck (Whitehouse and Harley, 2001). The bottlenecks of populations can increase rates of inbreeding, genetic variation loss and deleterious allele fixation. The bottleneck effect reduces the adaptation potential and threatens species/populations with extinction (Cornuet and Luikart, 1996). Frantz et al. (2015) provide strong evidence that selection at candidate genes (influencing anatomical and nervous system development) may have counteracted the homogenizing effect of gene flow.

Piry et al. (1990) created computer program BOTTLENECK, which is a set of tests that enable to identify if populations have recently experienced a severe reduction in effective population size. Especially in conservation biology the detection of bottlenecks is highly important because of population or species extinction. Most loci will exhibit heterozygosity excess in recently bottlenecked populations.

Due to the autochthonous origin of the PC breed and a small population size in the 1950s, the present study focuses on the analysis of genetic variability with an emphasis on recognizing a possible recent bottleneck.

\section{MATERIALS AND METHODS}

180 individuals of the local Prestice Black-Pied (PC) were analysed. DNA was isolated from blood, tissue or hair samples according to the isolation kit manual (Macharay Nagel). The Animaltype Pig Amplification Kit specifically developed for the genotyping of breeding livestock was used according to the manufacturer's recommendations. The multiplex PCR was applied for amplification of 11 STR markers: 387A12F, S0655, SBH1, SBH2, SBH4, SBH10, SBH13, SBH18, SBH19, SBH20, and SBH22 to specify various parameters of genetic diversity. STRs markers were separated by fragment analysis on genetic analyzer ABI PRISM 310 (Applied Biosystems, Foster City, USA). The fragment analysis was carried out using GeneScan 3.7 and Genotyper 3.7 software.
The heterozygosity excess test was used in the BOTTLENECK program. Tests for heterozygosity excess were performed by using three mutation models - the Infinite Allele Model (IAM), Two Phase Model of mutation (TPM) and Stepwise Mutation Model (SMM), which were used for running the BOTTLENECK program to test for population bottlenecks.

The BOTTLENECK v.1.2.02 (Cornuet and Luikart, 1996) software was used to find out basic population descriptive statistics - allelic frequencies, observed total number of alleles (TNA), effective number of alleles (Ae), observed (Ho) and expected heterozygosity (He). The IAM and SMM represent two extreme models of mutation, therefore the BOTTLENECK program uses both independently for testing bottlenecks. The sign test, the standardized differences test and the Wilcoxon's signed rank test were used to detect the significant number of loci with heterozygosity excess. For few $(<20)$ polymorphic loci the Wilcoxon's test is considered as the most powerful and robust.

One-tailed test requires at least four polymorphic loci to have possibility of obtaining a significant $(\mathrm{P}<0.05)$ test result. For bottlenecks testing the null hypothesis of the Wilcoxon's test is not significant for heterozygosity excess. The alternate hypothesis is significant heterozygosity excess thus evidence of a recent bottleneck. As the second test for potential bottleneck the Mode-shift indicator test was used.

\section{RESULTS}

The average number of tested alleles was 349.70 and the mean number of alleles in each locus was 7.50 (varied between 4-12). The lowest number of tested alleles occurred in SBH18 (presence of putative null allele). The highest total number of alleles in locus was detected in SBH2 and the lowest

I: Measures of 10 STR loci in the Prestice Black-Pied pig population

\begin{tabular}{lccc}
\hline & \multicolumn{3}{c}{ Observed } \\
\hline \multicolumn{1}{c}{ Locus } & $\mathrm{n}$ & TNA & $\mathrm{H}_{0}$ \\
\hline 387A12F & 360 & 7 & 0.699 \\
S0655 & 360 & 5 & 0.634 \\
SBH1 & 360 & 7 & 0.766 \\
SBH2 & 358 & 12 & 0.830 \\
SBH4 & 358 & 9 & 0.838 \\
SBH10 & 354 & 8 & 0.788 \\
SBH13 & 360 & 6 & 0.381 \\
SBH18 & 267 & 9 & 0.737 \\
SBH19 & 360 & 4 & 0.642 \\
SBH20 & 360 & 8 & 0.653 \\
\hline
\end{tabular}

$n$ : number of analysed alleles; TNA: total number of alleles in locus; $\mathrm{H}_{0}$ : observed heterozygosity 
II: Mutation models and heterozygosity tests in the PC population

\begin{tabular}{|c|c|c|c|}
\hline Models & Sign test & Standardized differences test & Wilcoxon test \\
\hline \multirow{4}{*}{ IAM } & Hee $=5.77$ & $\mathrm{~T} 2=2.983$ & P (one tail for $\mathrm{H}$ excess): 0.00146 \\
\hline & $\mathrm{Hd}=1$ & $p=0.00143$ & P (one tail for H deficiency): 0.99903 \\
\hline & $\mathrm{He}=9$ & & P (two tails for $\mathrm{H}$ excess and deficiency): 0.00293 \\
\hline & $p=0.03404$ & & \\
\hline \multirow{4}{*}{ SMM } & Hee $=5.90$ & $\mathrm{~T} 2=-2.789$ & P (one tail for H excess): 0.09668 \\
\hline & $\mathrm{Hd}=6$ & $p=0.00265$ & P (one tail for H deficiency): 0.91992 \\
\hline & $\mathrm{He}=4$ & & P (two tails for $\mathrm{H}$ excess and deficiency): 0.19336 \\
\hline & $\mathrm{p}=0.18287^{*}$ & & \\
\hline
\end{tabular}

Hee: heterozygosity excess expected; Hd: heterozygosity deficiency; He: heterozygosity excess; p: probability; ${ }^{*}$ nonsignificant p-value; IAM: Infinite allele model; SMM: Stepwise mutation model

number of alleles was in SBH19 locus. Observed heterozygosity ranged between 0.381 (SBH13) and 0.838 (SBH4) and mean $\mathrm{H}_{0}$ was 0.697 (Tab. I).

The results of the sign test show the expected number of loci with heterozygosity excess under IAM was 5.77, 1 locus with heterozygosity deficiency and 9 loci with heterozygosity excess, $\mathrm{p}=0.034$. All loci fit IAM and mutation-drift equilibrium. Under SMM the expected number of loci with heterozygosity excess was 5.90 ( $p=0.183$ ), 6 loci with heterozygosity deficiency and 4 loci with heterozygosity excess. All loci fit SMM and mutation-drift equilibrium. Standardized difference test shows that the hypothesis of mutation-drift equilibrium was rejected for IAM $(p=0.00143)$ and SMM ( $p=0.00265)$. The Wilcoxon's test confirmed that all loci fit IAM and SMM as same as population stays at mutation-drift equilibrium under both models (Tab. II).

In the mode-shift test the distribution of allele frequencies did not show a significant departure from a standard L-shape in the examined population.

Moreover, special alleles - outside declared range - were detected in six markers (387A12F, S0655,

III: Next alleles in the PC breed

\begin{tabular}{lcc}
\hline \multicolumn{1}{c}{ STR marker } & Allele & Size (bp) \\
\hline \multirow{2}{*}{ S0655 } & 23 & 491 \\
& 24 & 495 \\
& 25 & 499 \\
\hline SBH10 & 51 & 443 \\
\hline 387A12F & 52 & 447 \\
\hline SBH22 & 53 & 451 \\
\hline SBH19 & 22 & 259 \\
\hline SBH2 & 23 & 261 \\
\hline
\end{tabular}

SBH2, SBH10, SBH18 and SBH19) out of eleven in PC breed only. Compared with other commercial breeds just in PC breed there were specified three additional alleles in two markers, two new alleles in one marker and one extra allele in three markers (Tab. III). Putative null allele was detected in SBH18 marker. In this locus non-amplified alleles were observed in 16\% of all tested PC individuals. Deviation from Hardy-Weinberg equilibrium ( $p<0.001$ ) can confirm this hypothesis as well as He/Ho difference (He 0.836, Ho 0.616) - regardless of this marker variability (eleven different alleles in PC breed, PIC is 0.818).

\section{DISCUSSION}

Our findings of special alleles and putative null allele in the PC population can be explained by many causes, such as selection or bottleneck. Ferreira et al. (2009) pointed out that several private alleles and fragmented allele distribution can indicate bottlenecks in Portuguese wild boars. They found evidence of bottleneck in Portuguese boar population after the extreme reduction due to overhunting and swine fever in 1960s. Fragmented allele distributions frequencies can indicate bottleneck in population. In our previous study, specific alleles in Zlotnicka White and Zlotnicka spotted were described (Vrtková et al., 2017). In this Polish genetic resource breed, we found extra alleles in 387A12F marker. Similarly, the tested PC population is not panmictic but a small closed population. Krupa et al. (2015) claims in their comprehensive pedigree analysis of the PC breed that $100 \%$ of the genetic pool was explained by 66 ancestors. They describe a high risk of genetic diversity loss in the PC breed. On the other hand, Vrtková (2015) described allelic diversity pool in the $\mathrm{PC}$ and considered Ho $=0.70$ as sufficient. Harcet et al. (2006) illustrated low genetic diversity of autochthonous Croatian Turopolje pig breed and the need of further prevention of diversity loss. They did not find recent genetic bottleneck evidence and determined observed heterozygosity as 0.306 . 
Eleven European pig breeds were examined by Laval et al. (2000) and average observed heterozygosity was around 0.5. Average breed heterozygosity was assessed between 0.35-0.60. They revealed significantly reduced heterozygosity in the German Landrace compared with other examined breeds with genotypic frequencies in Hardy-Weinberg equilibrium. In comparison to Kramarenko et al. (2018) study of the bottleneck in Red Steppe cattle the observed heterozygosity was 0.607 and expected heterozygosity was 0.703 . They concluded the genetic variation of this population as high. It is considered as a good degree of genetic variation although the observed heterozygosity is lower than in Ukrainian Black Pied (0.821).
The bottleneck analysis was used for endangered species worldwide too. Rare alleles (frequency < 0.1) are most susceptible to loss in the bottlenecks. The loss of rare alleles rapidly changes frequency distribution, which is typical of recently bottlenecked populations. Whitehouse and Harley (2001) compared post-bottleneck genetic diversity in two elephant population and described $\mathrm{Ho}=0.192$ and $\mathrm{Ho}=0.422$, $\mathrm{He}=0.180$ and $\mathrm{He}=0.444$. Waldick et al. (2002) determined allelic diversity 3.2 and heterozygosity $\mathrm{H}=0.31$ in North Atlantic right whale, which was reduced from 12000 to 300. The genetic bottleneck did not occur but the genetic variability according to low frequency alleles has been reduced.

\section{CONCLUSION}

The study determined genetic variability of the national breed the Prestice Black-Pied pig, which is a genetic resource and at the same time a small closed population. According to different breeding history of this breed compared with commercial breeds, the question whether the PC breed suffered from bottleneck was investigated. Genotypes in STR markers were determined and genetic variability was analysed and examined by bottleneck analysis. The PC breed showed no bottleneck effect, although the analysis results were not as strong as in commercial breeds.

Acknowledgements

This paper was supported by NAZV QK1910400.

\section{REFERENCES}

CORNUET, J. M. and LUIKART, G. 1996. Description and power analysis of two tests for detecting recent population bottlenecks from allele frequency data. Genetics, 144(4): 2001-2014.

FALKOVÁ, L. and VRTKOVÁ, I. 2017. Searching for breed specific genetic markers of national genetic resource - the Přšstice Black-Pied Pig. In: Research in Pig Breeding. $16^{\text {th }}$ International workshop. 24-25 October 2019, Kostelec nad Orlicí - Vrbice.

FERREIRA, E., SOUTO, L., SOARES, A. M. V. M. and FONSECA, C. 2009. Genetic structure of the wild boar population in Portugal: Evidence of a recent bottleneck. Mammalian Biology, 74(4): 274-285.

FRANTZ, L. A. F., SCHRAIBER, J. G., MADSEN, O., MEGENS, H.-J., CAGAN, A., BOSSE, M., PAUDEL, Y., CROOIJMANS, R. P. M. A., LARSON, G. and GROENEN, M. A. M. 2015. Evidence of long-term gene flow and selection during domestication from analyses of Eurasian wild and domestic pig genomes. Nature Genetics, 47(10): 1141-1148.

GHOLIZADEH, M., RAHIMI, G., MAINJI, G. R. and ZADEH, H. S. 2008. Potential use of molecular markers in the genetic improvement of livestock. Asian Journal of Animal and Veterinary Advances, 3: 120-128.

HARCET, M., DIKIC, M. and GAMULIN, V. 2006. Low genetic diversity of the Turopolje pig breed. Food Technology and Biotechnology, 44(1): 105-109.

KRAMARENKO, A. S., GLADYR, E. A., KRAMARENKO, S. S., PIDPALA, T. V., STRIKHA, L. A. and ZINOVIEVA, N. A. 2018. Genetic diversity and bottleneck analysis of the Red Steppe cattle based on microsatellite markers. Ukrainian Journal of Ecology, 8(2): 12-17.

KRUPA, E., KRUPOVÁ, Z., ŽÁKOVÁ, E., KASARDA, R. and SVITÁKOVÁ, A. 2015. Population analysis of the local endangered Přeštice Black-Pied pig breed. Poljoprivreda/Agriculture, 21(supplement): 155-158.

LAVAL, G., IANNUCCELLI, N., LEGAULT, C., MILAN, D., GROENEN, M. A. M., GIUFFRA, E., ANDERSSON, L., NISSEN, P. H., JARGENSEN, C. B., BEECKMANN, P., GELDERMANN, H., FOULLEY, J. L., CHEVALET, C. and OLLIVIER, L. 2000. Genetic diversity of eleven European pig breeds. Genetics Selection Evolution, 32: 187-203.

MARUYAMA, T. and FUERST, P. A. 1985. Population bottlenecks and nonequilibrium models in population genetics. II. number of alleles in a small population that was formed by a recent bottleneck. Genetics, 111(3): 675-689. 
PIRY, S., LUIKART, G. and CORNUET, J. M. 1999. BOTTLENECK: A computer program for detecting recent reductions in the effective population size using allele frequency data. Journal of Heredity, 90(4): 502-503.

TORO, M. A., GARCIA-CORTES, L. A. and LEGARRA, A. 2011. A note on the rationale for estimating genealogical coancestry from molecular markers. Genetics Selection Evolution, 43: 27.

VÁCLAVKOVÁ, E., ROZKOT, M. and DOSTÁLOVÁ, A. 2012. Přeštické černostrakaté prase. Živé dědictví po predcích. Praha Uhříněves: VúŽV v.v.i.

VRTKOVÁ, I. 2015. Genetic admixture analysis in Prestice Black-Pied pigs. Archives Animal Breeding, 58: 115-121.

VRTKOVÁ, I, STEHLÍK, L., PUTNOVÁ, L., KRATOCHVÍLOVÁ, L. and FALKOVÁ, L. 2012. Genetic structure in three breeds of pigs populations using microsatellite markers in the Czech Republic. Research in Pig Breeding, 6(2): 83-87.

VRTKOVÁ, I., FILISTOWICZ, A., BUCZYŃSKI, J. T., VRTEK, Š. and FALKOVÁ, L. 2017. Parameters of variability and diversity of tetrameric STRs for practical use at Zlotnicka White and Zlotnicka Spotted pigs. Animal Science Papers and Reports, 35: 83-87.

WALDICK, R. C., KRAUS, S., BROWN, M. and WHITE, B. N. 2002. Evaluating the effects of historic bottleneck events: an assessment of microsatellite variability in the endangered, North Atlantic right whale. Molecular Ecology, 11: 2241-2249.

WHITEHOUSE, A. M. and HARLEY, E. H. 2001. Post-bottleneck genetic diversity of elephant populations in South Africa, revealed using microsatellite analysis. Molecular Ecology, 10(9): 2139-2149. 